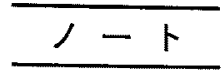

[睌化 第 46 巻，第 5 号，p. 267 271，1972]

$$
\text { ポリビニルピロリドンの定量法 }
$$

\author{
石川鹿生, 古市幸生, 中村 滋 \\ (三重大学振学部砫芸化学科)
}

昭和 46 年 8 月 19 日受理

Determination of Polyvinylpyrrolidone [Note]

By Shikao ISHIKawa, Yukio Furuichi and Shigeru Nakamura

Department of Agricultural Chemistry, Faculty of Agriculture, Mie University, Tsu

A simple spectrophotometric method was developed for the quantitative estimation of polyvinylpyrrolidone in some pharmaceuticals and biological materials.

The turbidity of polyvinylpyrrolidone precipitated by perchloric acid was measured turbidimetrically at $370 \mathrm{~m} \mu$. The absorbance due to the turbidity was directly proportional to the concentration of the polymer ranging from 1 to $4 \mathrm{mg}$ per $100 \mathrm{ml}$ of the final test solution. Biological materials should be extracted by water and be pretreated with Somogyi's precipitants in order to remove interference of turbidity with other materials.

(Received August 19, 1971)

ポリビニルピロリドン (PVP) は, 現在医薬品として 使用されているが，多くの興味ある性質を有する水溶性 重合体である(1).その高い溶解性と広い生理的適合性か ら，本重合体以動物の消化吸収を追跡するための指標物

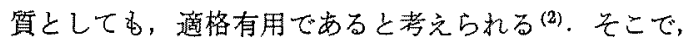
薬唷执よび生体試料中のPVPについて2，3の定量法を 試みてみた，その中て，過塩素酸により生成する濁度を 測定する方法が比較的簡易であり，Shiraeff ${ }^{(3)}$ がビール 中の高分子量の PVP K(4)-90 の定量に試みている.

著者らは，低分子量のPVP の濁り測定を採り上げ， 若干の検討を加克，動物の消化吸収研究のための指標物 質として用いる場合を想定して，その定量法を考案し た.

\section{試料, 試薬および装置}

試料 PVP として K-30 (General Aniline \& Film Corp.) を対象とし， 活か比較のため K-15（General Aniline \& Film Corp.), K-25 (Badische Anilin u.

Soda Fabrik) を用いた，山本らに上り求められたこれ らの粘度平均分子量は，それぞれ $37,200 ， 7,420,21,900$ である(5).
Levy ら ${ }^{(6)}$ の方法により測定した水分と不餙和度，キ ェルダール法に上る窒素および常法 ${ }^{(7)}$ とよる灰分は,

Table I に示すと和りである。

$0.1 \%$ PVP 液：PVP K-30 1.000g 常温汇て純水化 溶かし，1lにする。

$\mathrm{BaCl}_{2}$ 含有 $(10 \% \mathrm{w} / \mathrm{v}) 25.8 \% \mathrm{w} / \mathrm{v} \mathrm{HClO} \mathrm{H}_{4}$ 液 : $60 \%$ $\mathrm{HClO}_{4}$ (特級試薬) $100 \mathrm{ml}$ に，純水 $260 \mathrm{ml}$ を加兄る。こ の溶液で $\mathrm{BaCl}_{2} \cdot 2 \mathrm{H}_{2} \mathrm{O}$ (1 級試薬) $29.33 \mathrm{~g}$ を溶解せし め, $250 \mathrm{ml}$ とする.

$0.3 \mathrm{~N} \mathrm{Ba}(\mathrm{OH})_{2}$ 液 $: \mathrm{Ba}(\mathrm{OH})_{2} \cdot 8 \mathrm{H}_{2} \mathrm{O}$ (1 級試薬) $47.3 \mathrm{~g}$ を $\mathrm{CO}_{2}$ を除去した純水に溶かして，1lにたる。

$2.7 \% \mathrm{ZnSO}_{4}$ 液: $\mathrm{ZnSO}_{4} \cdot 7 \mathrm{H}_{2} \mathrm{O}$ ( 1 級試菜) $10 \mathrm{~g}$ 考純水 に溶功て, $200 \mathrm{ml}$ にする。

Table I. Grades of PVP Products

\begin{tabular}{lccc}
\hline & $\mathrm{K}-15$ & $\mathrm{~K}-25$ & $\mathrm{~K}-30$ \\
\hline Moisture & $0.98 \%$ & $2.42 \%$ & $3.84 \%$ \\
Nitrogen & 11.88 & 10.65 & 10.71 \\
Ash & 0.01 & 0.01 & 0.01 \\
$\begin{array}{l}\text { Unsaturation } \\
\text { as monomer }\end{array}$ & 0.85 & 0.14 & 0.39 \\
\hline
\end{tabular}


吸光度の湖定に心，島津 QB-50 型分光光度訣老使用

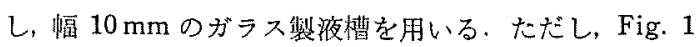
の吸取曲線を求める祭には，幅 $10 \mathrm{~mm}$ の石樭製液揹を 用いた。

\section{操作法}

PVP (5〜20 mg) を含む生体試料 $0.5 \sim 1.0 \mathrm{~g}$ 学科取 し, 純水 $20 \mathrm{ml}$ 学加觉て室温下で浸出する（液状武料は この操作老必要としない), $\mathrm{Ba}(\mathrm{OH})_{2}$ 液 $5.5 \mathrm{ml}, \mathrm{ZnSO}_{4}$ 液 $5 \mathrm{ml}$ (試料を多く取ら朴ぱなら場合は, 両液の容積 比を変えることなく適当化增量する）を添加して與拌 し，生じた沈殿を遠心分離して上澄液を $250 \mathrm{ml}$ 定容つ ラスコに移吉，遠沈管の残整に $20 \sim 30 \mathrm{ml}$ の純水を注加 して残存する PVP 浸出し，再び遠心分離して得られ る上澄液を同フラスコに取り入れ，純水を加克て $250 \mathrm{ml}$ に定容する，PVPを含む薬剂では，PVP の予想含量が $0.002 \sim 0.008 \%$ の筙围に入るよ5に, 定容の純水に溶 加与。

試料溶液と等容の $\mathrm{BaCl}_{2}$ 含有 $\mathrm{HClO}_{4}$ 液を混合して白 濁させ，室湿下で 60 分放置後，波長 $370 \mathrm{~m} \mu$ に和ける 吸光度を純水を標準として測定する，あらかじめ作成し た検量式により，PVPの含量を算出する.

\section{検埋式の作成}

$0.1 \% \mathrm{PVP}$ 液の $2,3,4,5,6,7,8 \mathrm{ml}$ 各々 $100 \mathrm{ml}$ 定容フラスコに取り，純水を加光て $100 \mathrm{ml}$ 火定容する. 各溶液 $5 \mathrm{ml} \mathrm{k} \mathrm{BaCl} 2$ 含有 $\mathrm{HClO}_{4}$ 液 $5 \mathrm{ml}$ を加えて白濁 巳せ，60分放置後，純水を標準として波長 $370 \mathrm{~m} \mu$ に就 ける吸光度を湘定する，PVPに対する吸光度の回愲は， Fig. 2 飞示与。 これより，次の検量式が求められる。

$$
\begin{aligned}
& \qquad y=13.7255 x+0.0088 \\
& x: \text { 吸光度 } \\
& y: \text { 最終溶液 } 100 \mathrm{ml} \text { 中の PVP } \mathrm{mg} \text { 数 }
\end{aligned}
$$

本定量操作に扣けるPVP 水溶液の濁度の吸光度に及 ぼす影暗と，PVP以外の白濁を起こす物質の存在が考 えられる生体試料の処理力法について検討した。

\section{PVP の白濁反応}

PVP は，その水溶液に過塩菜酸を加えると，沈降しが たい白色の分散粒子の形態をとる.この粒子は $1500 \times g$ 程度の遠心力により沈降し，液体部は透明となり，また 1 昼夜の放琶によってもその大部分が沈殷する。添加す る過塩素酸の濃度が高いと, 生じた粒子は溶解され消失 する，白濁肉腿で载別できるPVP下限溜度山，最終 溶液 $\mathrm{ml}$ 当り $3 \mu \mathrm{g}$ である. Fig. 1 に示すよ 5 に, 吸収

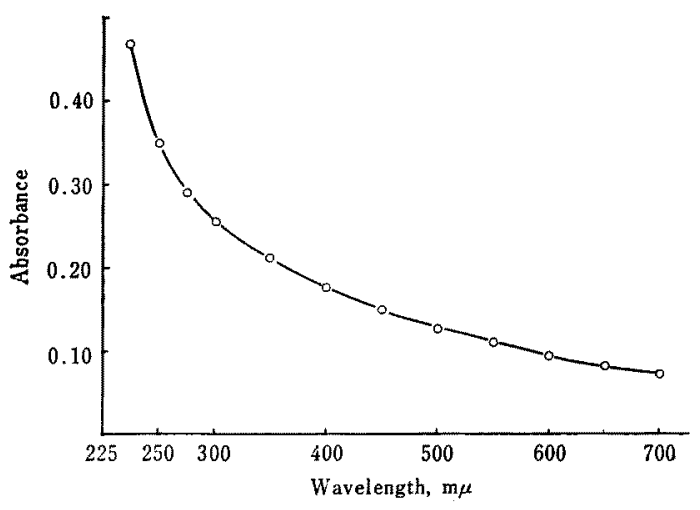

Fig. 1. Spectral Absorption of PVP-perchloric Acid Turbidity $30 \mu \mathrm{g}$ PVP/ml of Final Solution.

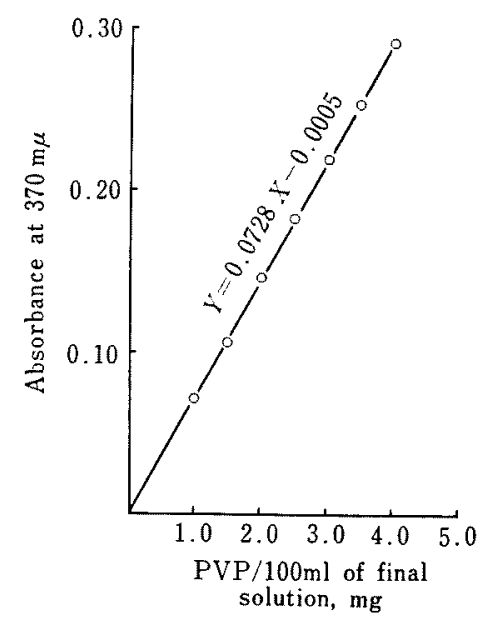

Fig. 2. Regression Curve.

曲線には極大点, 極小点がみからない. Shiraeff( ${ }^{(3)}$ が対象 としているK-90（分子壆 200,000）に比べ，低分子量の K-30 の濁度はきわめて低いので, 可視光線の範囲で測 定感度を高く寸るねらいから，370 $\mathrm{m} \mu$ を測定波長とし て採択した：この場合，最終溶液 $\mathrm{ml}$ 当り PVP 10〜40 $\mu \mathrm{g}$ の濃度範囲に括いて，Beerの法則にしたがう。

\section{過塩素酸の濃度}

PVP 溶液に等容の過塩素酸を加兄て白濁させること にし, 两溶液の濃度を変えて吸炕度を測定した結果は,

Fig. 3 に示すと括りである. 渦塩素酸の濃度が $20 \sim 30$ $\% \mathrm{w} / \mathrm{v}$ 付近で，極大吸光度を示すことがわかる.この ことから本法では, $25.8 \% \mathrm{w} / \mathrm{v} \mathrm{HClO}_{4}$ 液を用いている.

\section{PVP の重合度の影響}

K值すなわら重合度が高いほど吸光度は高い值を示す 


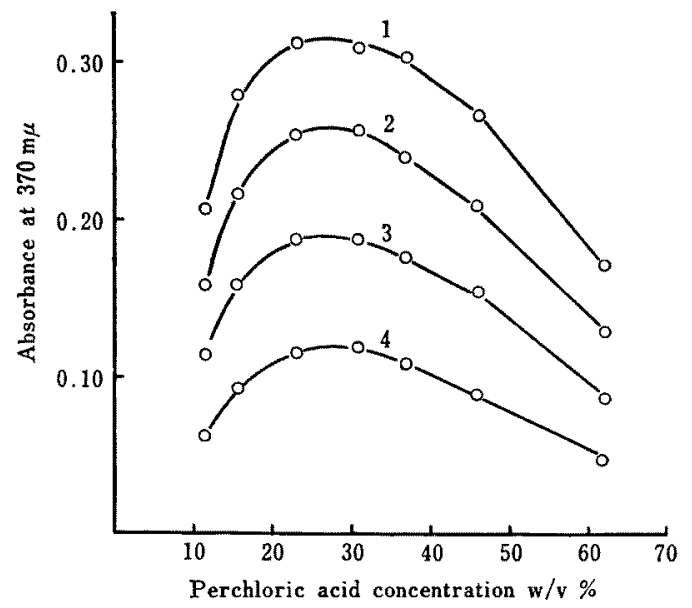

Fig. 3. Variations in Absorbance at Different Concentrations of Perchloric Acid. PVP $/ \mathrm{ml}$ of final solution: 1) $50 \mu \mathrm{g}$, 2) $20 \mu \mathrm{g}$, 3) $10 \mu \mathrm{g}$, 4) $5 \mu \mathrm{g}$.

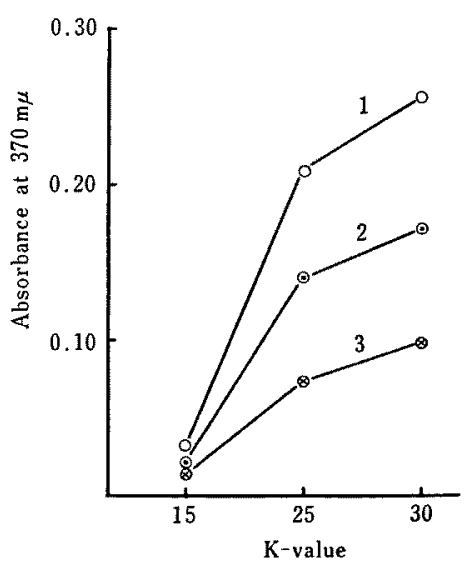

Fig. 4. Relation between $\mathrm{K}$-value and Absorption.

$\mathrm{PVP} / \mathrm{ml}$ of final solution : 1) $35 \mu \mathrm{g}$. 2) $25 \mu \mathrm{g}, 3) 15 \mu \mathrm{g}$.

ことが，Fig. 4 より明らかである、したがって本法によ る場合は，PVPの重合度別に，それぞれの検量式を作 成せねばならない。

\section{濁度促進物犋}

三塩化酢酸により生成するポリエチレングリコールの 濁度が，バリウムイオン存在下で促進されることが知ら れている(8)．本法に拈いても同じうな現象が類推され るので，2価の陽イオンであるカルシウム，マグネシウ ム、バリウム，西鉛について検討してみたすなおち， これらの塩化物をそれそれ $5 \%$ 含有する $\mathrm{HClO}_{4}$ 液によ
り PVP 液を白濁させ，吸光度を比較测定したところ， バリウムと無鉛がわずが白濁を促進することがわかっ た. 後に述べる沈殿剤の選択との関連を考慮して，パy ウムを使用することにし，その添加割合とPVP 粒子の 濁度の関係を調べた結果が, Table II である，塩化バリ ウムの添加量による影響はほとんどみられず，いずれる 吸光度值が対照より約 $10 \%$ 上昇する. したがって本法 では，塩化パリウムを $10 \% \mathrm{w} / \mathrm{v}$ 含有する $\mathrm{HClO}_{4}$ 液を発 色試薬とすることにした，湘定波長の選択と相まって， 本操作により測定感度を高くすることが可能になった。

\section{濁度の安定性}

室温下で PVP 液を発色試薬で白濁させ，経時的に吸 光度を測定した結果は Fig. 5 のと拈りである.白濁直 後から徐々下吸光度は上昇し，60分経過後は注安定を 保ら，120分経過すると，吝ずか低下寸る㑯向がみられ る.な招 $\mathrm{HClO}_{4}$ 液添加時の䚌拌は，吸光度の経時的変 化に影響を及ぼさない。

Table II. Effect of Barium Chloride on Absorbance

\begin{tabular}{|c|c|c|c|c|}
\hline \multirow{2}{*}{$\begin{array}{l}\mathrm{PVP} / \mathrm{ml} \text { of final } \\
\text { solution } \\
\mu \mathrm{g}\end{array}$} & \multicolumn{4}{|c|}{ 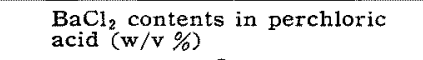 } \\
\hline & 0 & 5 & 10 & 15 \\
\hline 15 & $\begin{array}{r}0.0854 \\
(100)\end{array}$ & $\begin{array}{l}0.1051 \\
(123)^{*}\end{array}$ & $\begin{array}{r}0.1068 \\
(125)\end{array}$ & $\begin{array}{r}0.1068 \\
(125)\end{array}$ \\
\hline 25 & $\begin{array}{r}0.1650 \\
(100)\end{array}$ & $\begin{array}{r}0.1824 \\
(111)\end{array}$ & $\begin{array}{c}0.1844 \\
(112)\end{array}$ & $\begin{array}{r}0.1858 \\
(113)\end{array}$ \\
\hline 35 & $\begin{array}{r}0.2351 \\
(100)\end{array}$ & $\begin{array}{r}0.2541 \\
(108)\end{array}$ & $\begin{array}{c}0.2534 \\
(108)\end{array}$ & $\begin{array}{r}0.2549 \\
(108)\end{array}$ \\
\hline
\end{tabular}

* Ratio to control absorbance expressed as 100 .

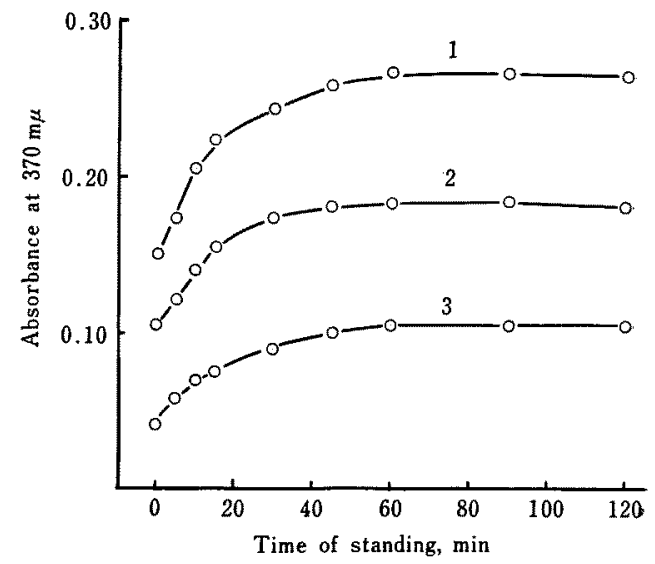

Fig. 5. Effect of Time on Absorbance. $\mathrm{PVP} / \mathrm{ml}$ of final solution : 1) $35 \mu \mathrm{g}$. 2) $25 \mu \mathrm{g}, 3) 15 \mu \mathrm{g}$. 


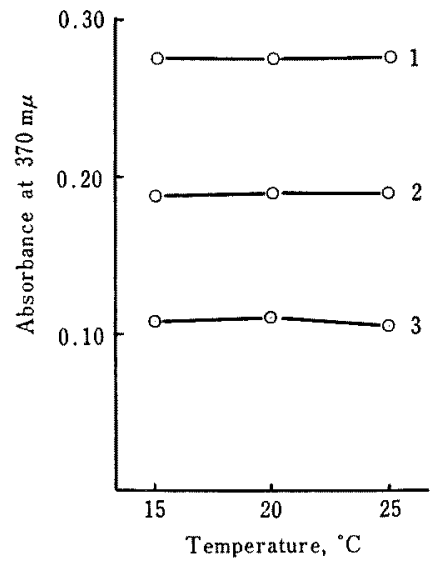

Fig. 6. Effect of Temperature on Absorbance. PVP/ml of final solution: 1) $35 \mu \mathrm{g}$,

2) $25 \mu \mathrm{g}, 3) 15 \mu \mathrm{g}$.

\section{温度の影笒}

室温付近の各温度に PVP 滺, 発色試薬を調節し, 白 濁せしめた場合の吸光度は Fig. 6 に示すを和りで，温 度による影響はないと考党られる。

\section{無機塩の影響}

General Aniline \& Film Corp. の説明畫(1)による と, $10 \%$ PVP 溶液に Table III の各無機塩溶液を混合 すると，コロイド状を呈するとしている。この現象が， 本法によるPVP 定量に及淁す影響について模討した。 炭酸ソーダと混合すると白濁コロイド状を呈するが，他 の無機塩との混合液は透明であり，10\% PVP 溶液の代 りに $5 \%$ PVP 溶液を用いて，PVPに対する無機塩の涺 合比を倍堌してb同結果を得た。

本法では，白濁化操作を施す前にPVP の濃度を測定 可能範囲に調製するため, $5 \%$ PVP の場合でも約 220 倍 の希釈を行ならことになり，その場合炭酸ソーがによる コロイド状は解消され透明となる。他の無機塩との混合 液についても，希积による外観の変化は2られない Table III の結果から, これらの無濑塩の存在は本法に

Table III. Effect of Inorganic Salts on Absorbance

\begin{tabular}{|c|c|c|c|}
\hline \multirow{2}{*}{ Inorganic salt } & \multirow{2}{*}{ Salt added $\underset{\substack{\% \sigma^{*}}}{ }$} & \multicolumn{2}{|c|}{ Recovery $\%^{* *}$} \\
\hline & & $10 \% \mathrm{PVP}$ & $5 \% \mathrm{PVP}$ \\
\hline Sodium carbonate & 185 & $101.1 \pm 0.49$ & $103.6 \pm 0.98$ \\
\hline Sodium phosphate, dibasic & 370 & $100.4 \pm 2.19$ & $102.1 \pm 0.64$ \\
\hline Sodium phosphate, tribasic & 128 & $100.2 \pm 0.86$ & $102.4 \pm 1.31$ \\
\hline Sodium metasilicate & 300 & $98.2 \pm 0.57$ & $104.3 \pm 1.02$ \\
\hline
\end{tabular}

* Per cent by volume of $10 \%$ salt solution added to $10 \%$ and $5 \%$ PVP solution respectively, ** 4 analyses: mean $\pm S . D$.
よる PVP 定量を阻軲しないことがわかる。

\section{沈殿刜の選杓}

生体液状試料または生体試料からの PVP 抽出液に蛋 白が溶存すると，たとえ無色透明であっても過唔菜酸に より蛋白粒子が形成され，PVP の濁度に影響を及仿す。 本卖験では，各種の除蛋白法を試みた絬果，Somogyi 法 ${ }^{(9)}$ にって澄明な上澄液が得られ，てこにPVPがほ ぼ完全に移行することがわかった.たたし本法に批いて は, 白濁促進のため $\mathrm{HClO}_{4}$ 液に加光てある塩化バリウ ムが，酼酸イオンと反応して白色粒子を形成することが ない上らに, Somogyi 試薬の使用に際し $\mathrm{Ba}(\mathrm{OH})_{2}$ 液と $\mathrm{ZnSO}_{4}$ 液の容積比を $1.1: 1$ にして, 除蛋当後の溶液中 に和ける硫酸イオンの残留を就さえている。

著者らが取り报った次に述べる生体試料では，除蛋白 操作を施した白濁化前の PVP 含有希瀵溶液は，すべて 無色透明であった。しかし，な怙混濁または着色が残 る場合は，あらかじめ消去せねばならない。この場合 活性炭，酸性白土は PVPをる吸着するので使用できな い. 適当な脱色方法が見つからないときは，着色液の吸 光度を盲験値として差引計算による方法が考えられ， Shiraeff(9) はこの方式によりビール中の PVP K-90の 定量を行なっている、しかし，その報告は濁り湘定に拉 ける諸条件についての具体的記述に乏しい。

\section{薬放中の PVP 回収実験}

PVPは，Table IV に示す数種の薬放と複合体を作 り，薬作用の持続化をもたらすとされている(10).このよ らな状態のPVPの定量に本法を応用して回収成績を求 めた結果が, Table IV K示されている.すなわる, PVP と各薬润を 1:20 の重量比で溶かした水溶液を $36^{\circ} \mathrm{C} の$ 亘温器内に 8 時間静置した後, 取り出して定量分析を行 なった.フェノバルビトールとサルファチアゾールは水 に対する溶解度が低いため，水溶液中の濃度を他の薬用 と同一にすることがでさなかった．また薬珮の量をPVP の 20 倍量としたのは, Müller ${ }^{(\mathbf{1 1})}$ が錠剂成分中の PVP 定量害験に用いている例にならった。

薬绪中の PVP 定量に，本法が適用 できることがわかる。

\section{生体試料中の PVP 回収実験}

生体試料として，市沮豚用飼料給与 により飼育した成豚の䔬と尿，および 尿殺時に採取した血液を用いた。

㲦燥翼 $0.5 \mathrm{~g}$ ，尿 $1 \mathrm{ml}$ およびクエン 
Table IV. Recovery of PVP in Presence of Pharmaceuticals (\%)

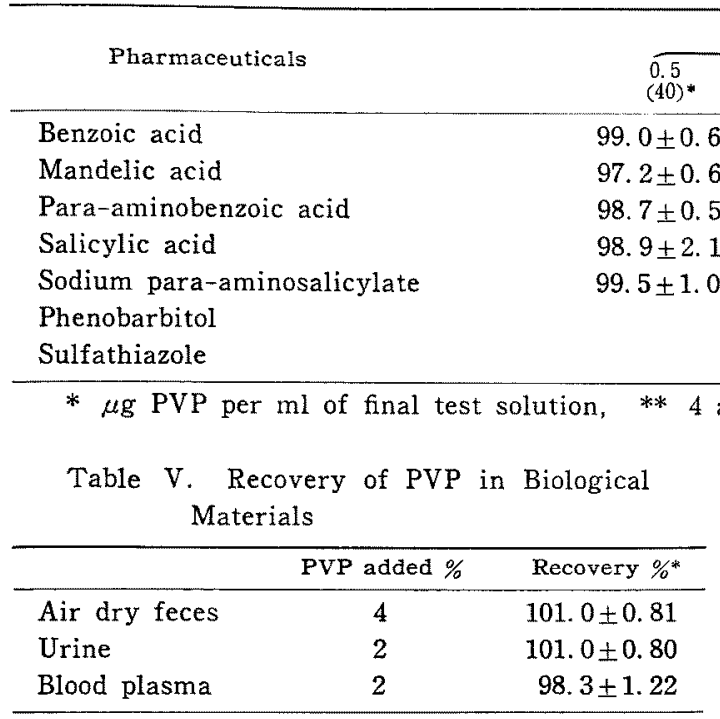

* 4 analyses : mean $\pm S$. D.

酸ソーダを加えた血液を遠心分離して得られた血将 $1 \mathrm{ml}$ に，それぞれ $0.1 \%$ PVP 液 $20 \mathrm{ml}$ を混和して，室温下 で 1 昼夜放置した後，所定の操作にしたがいPVP定 量した結果，Table V に示すと晾り，良好な回収率が 得られた。

(1) General Aniline \& Film Corp., New York : “PVP, An Annotated Bibliography” (日本語 訳), 1951, p. 17 .
Pharmaceuticals in aqueous solution $\%$

\begin{tabular}{llll}
\hline 5 & 0.25 & 0.1 & 0.05 \\
$(40)$ & $(20)$ & $(24)$ & $(12)$
\end{tabular}

$101.9 \pm 1.29$

100. $0 \pm 0.42$

$103.3 \pm 1.75$

$102.8 \pm 1.05$

$100.8 \pm 0.76$

$102.9 \pm 0.64 \quad 95.1 \pm 0.45$

$102.7 \pm 1.00 \quad 94.3 \pm 0.55$
05 . . 